\title{
MODERNIZATION OF PRIMARY SCHOOL TEACHERS' TRAINING: FROM KNOWLEDGE TO COMPETENCE APPROACH
}

\author{
Valentine Grinyova \\ Kharkiv National Pedagogical University named after G.S. Skovoroda, Kharkiv, Ukraine \\ kvn.grineva@gmail.com \\ Oksana Rezvan \\ Kharkiv National Pedagogical University named after G.S. Skovoroda, Kharkiv, Ukraine \\ rezvanoksana1@gmail.com
}

\begin{abstract}
The article discusses the problem of training primary school teachers regarding reforming primary education in Ukraine on the basis of competency-based approach. The principles of organisation of education process consist in forming interdisciplinary (multicultural) knowledge and skills as well as the ability to function effectively in the conditions of global changes. The major issues of primary education to be taken into account in teacher preparation are: teaching children to use the acquired knowledge in life and correspondence of education content and methods to students' age peculiarities. The competences to be formed in children fall into two categories: key competences (communicative, math, technology, information, interpersonal, intercultural, social, etc.) which provide the ability to use the obtained knowledge in problem-solving; subject competences being reflected in education curricula. The article presents the basic principles of developing motivation and self-motivation which are the basis of competence approach: subject competences (what we teach) should be formed on the basis of key competences (why we teach). The ideas of educational freedom and responsibility of teachers are discussed in the article.
\end{abstract}

Keywords: competence; competence approach; primary school; reformation of education, teacher preparation.

\section{Introduction}

There is an urgent need in modern society to develop the personality being able to survive in the conditions of economic, political, environmental, moral and ethical crises. A man of the future should be prepared to maintain effective social life facing rapidly changing information, globalisation and integration of cultures. Thus, the problem causes the necessity to review scientific approaches concerning the philosophy of education in general and basic education in particular and therefore training primary school teachers.

The aim of the article is to determine the key issues of training primary school teachers to work in the conditions of reforming secondary education on the basis of competence approach. In order to achieve this aim, we will discover core competencies to be formed in school children, analyse the development of competence approach in educational system of many countries, present strategic issues of reforming of Ukrainian educational system according to the ideas of competence approach, distinguish the main problems in the process of junior school teacher's training for competence approach.

\section{Analysis of current global trends in secondary education}

The dynamic of modern life significantly affects the approaches in the educational process in all developed countries. These include the development of decision-making skills, the ability to use information technologies and effectively communicate in multicultural society. In the European framework of social development, forming personal competencies necessary for effective functioning in a society is concerned with the development of problem-solving skills. The European Parliament published the guidance on determining the core competencies as a basis for effective interpersonal communication (Recommendation of the European Parliament, 2005). In particular, the following competencies were mentioned:

1. Communication in the mother tongue which is a necessary condition for full participation of the individual in society;

2. Communication in foreign languages which allows perceive and interpret foreign language speech according to social contexts;

3. Mathematical competence and basic competences in science and technology, found in the ability to perform various kinds of calculations to solve a number of everyday problems, to use facilities and devices necessary for comfortable life, to use the obtained knowledge for making conclusions based on the facts;

4. Digital competence which is the ability to use different kinds of software to work with information, texts, multimedia databases and organise communication, etc.;

5. Learning to learn which is recognising and using the opportunities of self-development, defining goals and strategies of self-changing quality and methods of training; 
6. Social and civic competences which are the capacity of individuals to participate effectively in social and professional life. This competence refers to a physical and mental health, formation of the ideas about moral and social standards of life, the ability to find a balance between personal life and professional activities, as well as the ability to think critically and to comply with the regulations in human rights, tolerance position regarding the value of the individual;

7. Sense of initiative and entrepreneurship is individual's ability to turn ideas into action. This competence is caused by the formation of human abilities to plan, organise activities, manage the progress, analyse and predict results, assess risks and own resources, to work in a team and identify leadership qualities and motivation, persistence in achieving goals;

8. Cultural awareness and expression which is expressed in understanding the importance of the creative expression of ideas, experiences and emotions. This competence includes the knowledge of classical art, major cultural achievements of civilisation, modern culture trends.

According to this document, "competence" is viewed as a combination of knowledge and skills in a certain context (Recommendation, 2005, p.11). We consider this definition to be quite acceptable and believe that competence refers to the level of formation of person's skills in a particular field.

Core competencies have to be formed in a secondary school so that in the adulthood a person will be competent either in obtaining further education (the ability to learn) or in professional activity (Standards Ukraine, 2016, p. 2). The key issue here is the development of complex competences based on the most significant existing basic competences such as speech and language, mathematical and information ones. In addition, it is important to form functional competences which result in critical thinking, creativity, initiative, risk assessment, decision-making, self-control, etc.

A great number of core competences defined by international community led to generalisations of their types by certain scientists. Thus, according to Shpytalevska's research on the analysis of identifying key competences, it is proposed referring them to the blocks such as social, motivational and functional ones (Shpytalevsjka, 2011, p. 224).

Consequently, it is important to form in young people core competences in order to develop general life competence. This process may be maintained the most effectively on the condition of realisation in the system of education in a particular state.

Researching the Ukrainian secondary school curricula of recent past revealed that the knowledge-based approach that determined the quality of preparing school-leavers has become retrograde for today's changing world. Thus, there is a need for new concepts of secondary education which will be effective for the formation of the future.

Hence, there is a need to implement new concepts of secondary education in order to educate a man of the future.

In the mentioned aspect, the idea of the actual effectiveness of building educational strategies on the basis of competence approach that gives the ability for children to apply knowledge to solve different kinds of problems, integrate them in various areas of life, and be independent in acquiring information and mobile in its application has become popular today.

\section{Analysis of scientific studies on the use of competence approach in education}

The problem of competence approach in scientific discourse is not new. Analysis of current research in this field distinguishes the importance of the issue which is represented at the national level in different countries. Thus, Kazakova (2015) analyses European education systems according to the list of key competences to be formed in young generation. According to the author, using competence approach in education is caused by the requirements of Organisation for Economic Co-operation and Development (OECD) regarding effective human functioning in information society. For this reason, it is necessary to change the system of values where the formation of knowledge and skills is necessary but not sufficient education result.

In recent years, research on training professionals in various fields on the basis of competency approach has become quite popular. Anoshkova (2015) defines global competence as fundamental in the formation of future specialists' competitiveness in the conditions of globalisation. The scientist claims that global competences include academic dimension which is the knowledge of history, geography and global problems of humanity; action dimension which is the ability to communicate with foreign speakers; ethical dimension which develops positive attitude towards cultural diversity, global recognition of human values, respect for the uniqueness of each nation (p. 6). The author believes these formed competences will allow young people to build professional career successfully in any country as such specialists will be tolerant in perception of values and behaviour of representatives of other cultures as well as have dynamic and adaptive professional behaviour, which will lead to self-realisation. 
Several publications have appeared in recent years documenting the significance of competence approach realisation in the educational systems of Great Britain, France and Germany (Mulder, et al., 2007). The interest to the problem is caused by a number of specific issues related to educational and social trends. These are the complexity of determining the principles of competency-based education which are defined in the curriculum; inadequate assessment of competency-based education; problems in evaluating the level of professional competence formation, causing difficulties in hiring employees.

Researchers of the basic competency-based curriculum in Spain consider a competence as an ability to meet complex requirements which is possible due to the mobilisation of all resources and skills in problemsolving (Pamies et al., 2015). The authors are guided by the document "Combining core competences as a necessary element of the work program" (OECD) and note that combination of core competences in job training programs allows to focus on the training concept in which the acquired knowledge and skills are evaluated as a preparatory stage for "how to do" learning or as a useful application of competences.

The Swedish scientists refer to the same document in the research of competency-based approach in teacher training. The scientists (Arnet-Clark et al., 2015) state that the core competences such as critical thinking, communicative interaction and creativity are necessary for professionals in the XXI century. It is stressed that a competence is more than formed knowledge and skills. For example, the communication competence is based on the knowledge of languages, interpersonal communication skills, practical skills in IT.

According to the documents of Commission of the European Communities (2005) the total professional competence includes cognitive (knowledge), functional (skills) and personal (abilities) components. The majority of scientists support this classification. However, some researchers (Jeljnykova et al., 2010) point out the hierarchical nature of competence formation, where obtaining professional competence is based on forming basic (key), general professional and special competences. Basic competences are revealed in the context of structure of human activity; general professional competences refer to certain professional fields, for example, humanitarian, economical, psychological, etc.; special competences are obtained during professional training in certain fields.

Ukrainian and Russian scientists take into account international experience of personality-oriented education which is implemented on the basis of competence approach. In particular, Bibik (2015) notes that competency-based education shifts from the accumulation of knowledge to the formation of problem-solving skills where causal relationships are unknown. Only in this case, the conditions for competence mechanisms (the ability to act in particular circumstances) and achievement motives arise (p. 52).

The researchers emphasise the need to use modern teaching methods and means, in particular, casemethod, project-based learning, which is effective in forming reflexive, search research, communication, presentation, teamwork competencies (Gholub, 2015, p. 114).

Thus, modern education of any level would be effective when implemented on the basis of competence approach aimed at distinguishing and developing core competencies necessary for self-realisation in a modern world.

\section{Trends in primary school reform in Ukraine}

The current trends in secondary education in Ukraine are defined in terms of its reforming according to the standards of European education system. This issue demands the revision of education standards, curricula, secondary school structure. The changes in the secondary school are associated with its transition to competence approach. The President of the Academy of Educational Sciences of Ukraine Vasyl Kremen has defined the strategic issues of secondary education development: life-long learning; the ability to obtain new information; learning to use the knowledge. It should be noted that the major issue of competence approach is the use of knowledge in life.

Primary school reform in Ukraine is aimed at adopting competence approach, which is currently being implemented in a secondary education. Thus, at the meeting of the board of the Ministry of Education and Science of Ukraine on April, 8 in 2016 the changes to the primary school curriculum (1-4 grades) were discussed taking into account the new approaches to teaching children. The basic ideas raised during this event are:

- preparing children for life through the mastery of specific competences during learning;

- reforming curricula on the basis of competence approach;

- correction of fundamental learning objectives;

- changes in the learning assessment according to the age psychological features of young children to ensure they feel comfortable (cancel teachers' red pen which allows not to fear to make mistakes); 
- review the functions of the Institutes of Continuing Education, which should become the centres of practical implementation of competence approach by providing online resources with the access to video lessons which based on competence approach;

- pedagogical freedom of teachers, i.e. independence in determining the number of hours to study specific curricular topics. Teachers should take into account students' individual characteristics.

However, these ideas have raised certain problems which should be taken into account. For instance, some teachers may neglect the adopted changes in the curriculum. In this case, methodical commissions should constantly monitor the process of implementation of new standards in primary education. Another problem refers to changes in educational standards. As in every class, there are students with different levels of learning ability, in the definition of standards the attention should be focused on differentiating the levels of competences. The curriculum should be supplied by options that allow to raise children's interest in learning and to provide pedagogical freedom of teachers. The issue of banning assessment of achievements of primary school children has raised a discussion. Some scientists expressed the idea that the replacement of pens by pencils in performing written assignments and banning red-pasted pens for teachers, on the one hand, will allow students not to fear mistakes, and on the other hand it will make it impossible to focus on one's own imperfections, and to return to the unsatisfactory outcome in order to practice certain gaps in knowledge.

\section{Conclusions}

In the article, we have distinguished the core competences to be formed in a primary school. On the basis of the analysis of implementing competence approach in different countries and according to the strategic issues of primary education reforming in Ukraine the need arises to correct the approaches to training primary school teachers. Thus, it is necessary to teach children taking into account their age features and active resources. Forming core competences that will help children maintain effective social interaction through implementing knowledge and skills in decision-making should be defined in the curriculum.

In our future research, we intend to concentrate on the analysis of the effectiveness of methodical aids on the implementation of competence approach in primary school teaching.

\section{References:}

Anoshkova, T. A. (2015). Implementation of global competency in higher education. Advanced Education, 3, 4-8. http://dx.doi.org/10.20535/2410-8286.43743

Arnet-Clark, I., Smeets-Cowan, R. \& Kühnis, J. (2015). Competences in Teacher Education at Schwyz University of Teacher Education (HHSZ), and the Swiss Education Policy. Pädagogische Hochschule Schwyz, 88-100. Retrieved from http://www.phsz.ch

Bibik, N. M. (2015). Perevaghy i ryzyky zaprovadzhennja kompetentnisnogho pidkhodu v shkiljnij osviti [The Benefits And Risks Of Introducing Competency Approach In Preschool Education]. Ukrajinsjkyj pedaghoghichnyj zhurnal, 1, 47-58.

Gholub, N. B. (2015). Konceptualjni zasady suchasnoji metodyky navchannja ukrajinsjkoji movy v zaghaljnoosvitnij shkoli [Conceptual Foundations Of Modern Methods For Teaching The Ukrainian Language In Secondary School]. Ukrajinsjkyj pedaghoghichnyj zhurnal, 1, 107-118.

Jeljnykova, Gh. V., Zajchenko, O. I. \& Maslov, V. I. (2010). Teoretychni $i$ metodychni zasady modeljuvannja fakhovoji kompetentnosti kerivnykiv zakladiv osvity: monoghrafija [The Theoretical And Methodological Foundations Of Modeling Professional Competence Of Heads Of Educational Institutions]. Kyiv-Chernivtsi, Ukraine: Knyghy - XXI.

Kozakova, N. B. (2015). Realizacija kompetentnisnogho pidkhodu v navchanni molodshykh shkoljariv [The Implementation of Competence Approach in Primary School Children Teaching]. Forum of pedagogical ideas "Urok". Retrieved from http://osvita.ua/school/lessons_summary/edu_technology/31210/

Ovcharuk, O. V. (2004). Kompetentnisnyj pidkhid u suchasnij osviti: svitovyj dosvid ta ukrajinsjki perspektyvy: Biblioteka z osvitnjoji polityky [Competence Approach In Modern Education: World Experience and Ukrainian Prospects]. Kyiv, Ukraine: K.I.C.

Pamies, J., Blanco, A., Granados Sanchez, J. \& Villanueva, M. (2015). The introduction of a competence-based curriculum in Spain: From the Primary school to the training of teachers. Ćasopis e-PEDAGOGIUM. Vydává Pedagogická fakulta Univerzity Palackého v Olomouci, 2, 72-84.

Recommendation of the European Parliament and of the council on key competences for lifelong learning (2005). Commission of the European communities, Brussels. Retrieved from http://jows.pl/sites/default/files/KE_European\%20Indicator\%20of\%20La nguage\%20Competence_2005.pdf

Shpytalevsjka, Gh. (2011). Kharakterystyka kljuchovykh ta predmetnykh kompetentnostej ta kompetencicj osobystosti [Description Of Key Competences And Subject Competence And Personality]. Problemy pidghotovky suchasnogho vchytelja, 4 (2), 220-225.

Standards Ukraine. (2016). Rishennja koleghiji Ministerstva osvity j nauky Ukrajiny № 8/12 vid 04.08 2016. Pro vnesennja zmin do navchaljnykh proghram dlja 1-4 klasiv zaghaljnoosvitnikh navchaljnykh zakladiv [On Amendments To The Curriculum For 1- 4 Classes Of Secondary Schools]. Retrieved from http://www.mon.gov.ua

Mulder, M., Weigel, T. \& Collins, K. (2007). The concept of competence in the development of vocational education and training in selected EU member states: a critical analysis. Jornal of Vocational Education \& Training, 1, 67-88. https://doi.org/10.1080/13636820601145630 